This is an Open Access article, distributed under the terms of the Creative Commons Attribution licence (http://creativecommons.org/licenses/by/4.0/), which permits unrestricted reuse, distribution, and reproduction in any medium, provided the original work is properly cited.

\title{
Exploring Site Formation and Building Local Contexts through Wiggle-Match Radiocarbon Dating: Re-Dating of the Firth of Clyde Crannogs, Scotland
}

\author{
Piotr Jacobsson $^{1}$, Alex G.C. Hale ${ }^{2}$, Gordon Сook $^{1}$ and Derek Hamilton ${ }^{1}$ \\ ${ }^{1}$ Scottish Universities Environmental Research Centre, University of Glasgow, UK \\ ${ }^{2}$ Historic Environment Scotland, Edinburgh, UK
}

There are at least four wooden intertidal platforms, also known as marine crannogs, in the Firth of Clyde, on the west coast of Scotland. The interpretation of these sites partly depends on their dating and, if coeval, they could point to the presence of a native maritime hub. Furthermore, the spatial coincidence with the terminus of the Antonine Wall has led to speculation about the role they may have played in Roman-native interaction during the occupation of southern Scotland in the early first millennium cal AD. Hence, a better absolute chronology is essential to evaluate whether the marine crannogs were contemporary with one another and whether they related to any known historic events. This article presents results of a wiggle-match dating project aimed at resolving these uncertainties at two of the sites in question, Dumbuck and Erskine Bridge crannogs. The results show that the construction of these sites pre-date direct Roman influence in Scotland. Furthermore, the results indicate that the two sites were built at least 300 years apart, forcing us to consider the possibility that they may have functioned in very different historical contexts. Other findings include technical observations on the fine shape of the radiocarbon calibration curve near the turn of the first millennia BC/AD and potential evidence for persistent contamination in decayed and exposed sections of waterlogged alder.

Keywords: radiocarbon wiggle-match dating, Bayesian chronologies, Iron Age Scotland, crannogs, intertidal settlement, Firth of Clyde

\section{INTRODUCTION}

Since the late nineteenth century, wooden platforms that are often referred to as 'marine crannogs' have been known in the Firth of Clyde (the estuary of the river Clyde) (Bruce, 1900, 1908). Yet, while their presence is well recognized and some ideas regarding their possible function have been put forward (Hale, 2004), their relationships to one another, as well as their broader regional context, remain elusive on account of imprecise chronology. Unless these sites can be placed into specific centuries, the question remains as to whether they may have been contemporary and formed a kind of early maritime hub linked to some (pre-)historic event, or whether they may have been part of a more extensive tradition spanning several centuries. Building chronologies to resolve these alternatives faces two main challenges: 1) they require precision of less than a century; 2) they need to be robust to account for the 


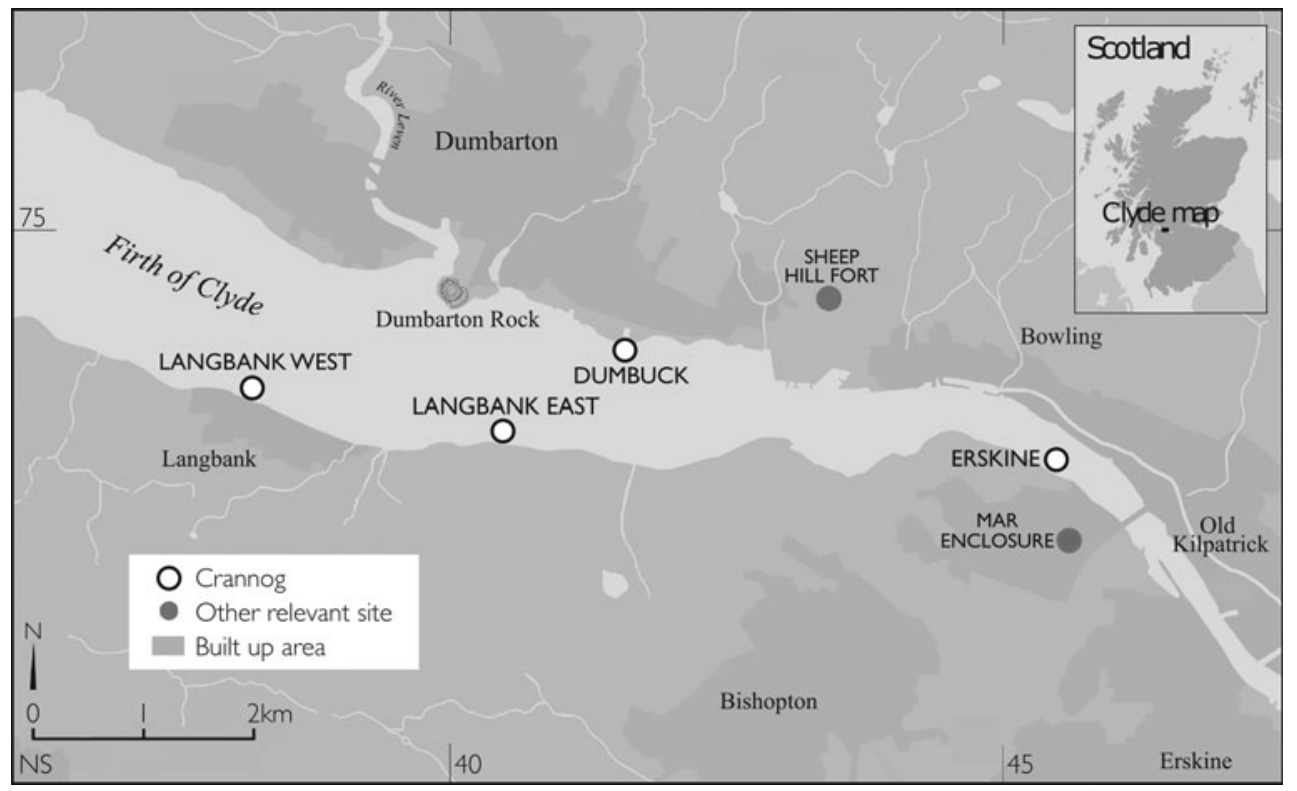

Figure 1. Map of the Firth of Clyde showing the four marine crannogs.

(c) Crown Copyright Historic Environment Scotland.

possibility that some of the structural timbers encountered were re-used. This article discusses how, through the use of radiocarbon wiggle-match dating and a feature-oriented approach to sampling, these challenges were overcome at two of the Clyde marine crannogs, Dumbuck (https:// canmore.org.uk/site/43402/dumbuck) and Erskine Bridge (https://canmore.org.uk/site/ 43313/erskine-bridge) ${ }^{1}$ (Figure 1).

\section{Archaeological Background}

The first recorded investigations of the marine crannogs in the Firth of Clyde date to the end of the nineteenth century, when the earliest stages of Scottish wetland archaeology were coming to an end (Dixon, 1991). The first excavation, at the site of the Dumbuck crannog, was undertaken in 1898-89, under the

1 Canmore ID numbers refer to the identification of the sites in the Historic Environment Scotland National Collection online database 'Canmore' (https://canmore. org.uk/; last accessed 24 August 2017). direction of John Bruce and William Donnelly (Bruce, 1900). This project is perhaps best known for producing multiple forged figurines of black slate, leading to a subsequent scandal and making it synonymous with false antiquities (Hale \& Sands, 2005). Nevertheless, the structure itself, which consists of a circular wooden floor or sub-floor and a canoe dock, was genuine. In subsequent years, John Bruce (1908) moved on to excavate another Clyde marine crannog, Langbank East; but, thereafter, research on these structures ceased until the late 1980s, when William Hanson from the Department of Archaeology, University of Glasgow, undertook a photogrammetric survey of the Erskine Bridge crannog (Hale, 2000). This was followed by further surveys in the 1990s by Hale (2004) and a smallscale re-excavation of the Dumbuck crannog, which is perhaps most notable for yielding a wealth of environmental remains despite the very limited scope of the exposure (Miller \& Ramsay, 2001). 
From these investigations, some basic characteristics of the surviving Clyde marine crannogs became clear. First, all the sites in question have surviving timbers and a substantial stone component. From the early excavations of the Dumbuck and Langbank East crannogs, as well as the undisturbed remains of the Langbank West crannog, we know that these formed circular mounds, where the stone would have capped the underlying timbers. The archaeological deposits at these sites appear to have been shallow in most cases; once again, we know from earlier descriptions and modern observations that the mounds themselves never rose much above the surrounding intertidal mud. Furthermore, the 1999-2001 excavations at the Dumbuck crannog showed that the deposits there might not run any deeper than two layers of what appears to have been foundation timbers (Miller \& Ramsay, 2001). Where the structural evidence survives in good condition, it is clear that the original buildings would have been circular, or would have had a substantial circular component, with little to suggest subsequent rebuilding (Hale \& Sands, 2005). Hence, while final judgement must be withheld until more extensive excavations become possible, current data suggest that the marine crannogs in the Firth of Clyde were single-occupation entities, as suggested in Hale (2004).

Of the four known marine crannogs, Dumbuck and Erskine Bridge are the two that are best understood, and these form the main subject of this article. They were chosen on the basis of limited earlier dating evidence and their exposed condition, which made sampling easier and possible without disturbance to the archaeological deposits. The first of these sites, Dumbuck, had already been the target of an antiquarian excavation that left the wooden component of the site uncovered. The structure itself consists of an oak post-ring encircling a

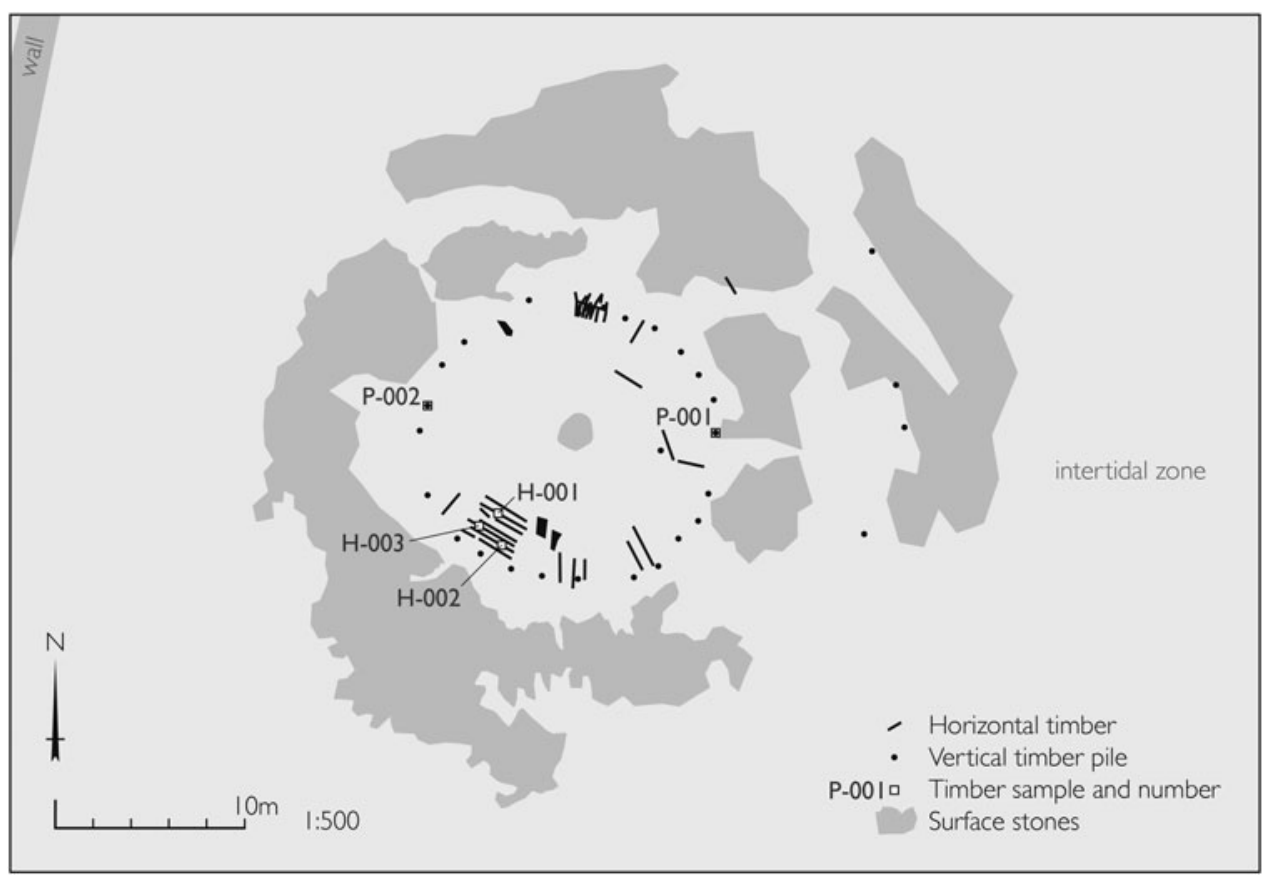

Figure 2. Plan of the Dumbuck crannog with the sampled timbers highlighted.

(c) Crown Copyright Historic Environment Scotland. 


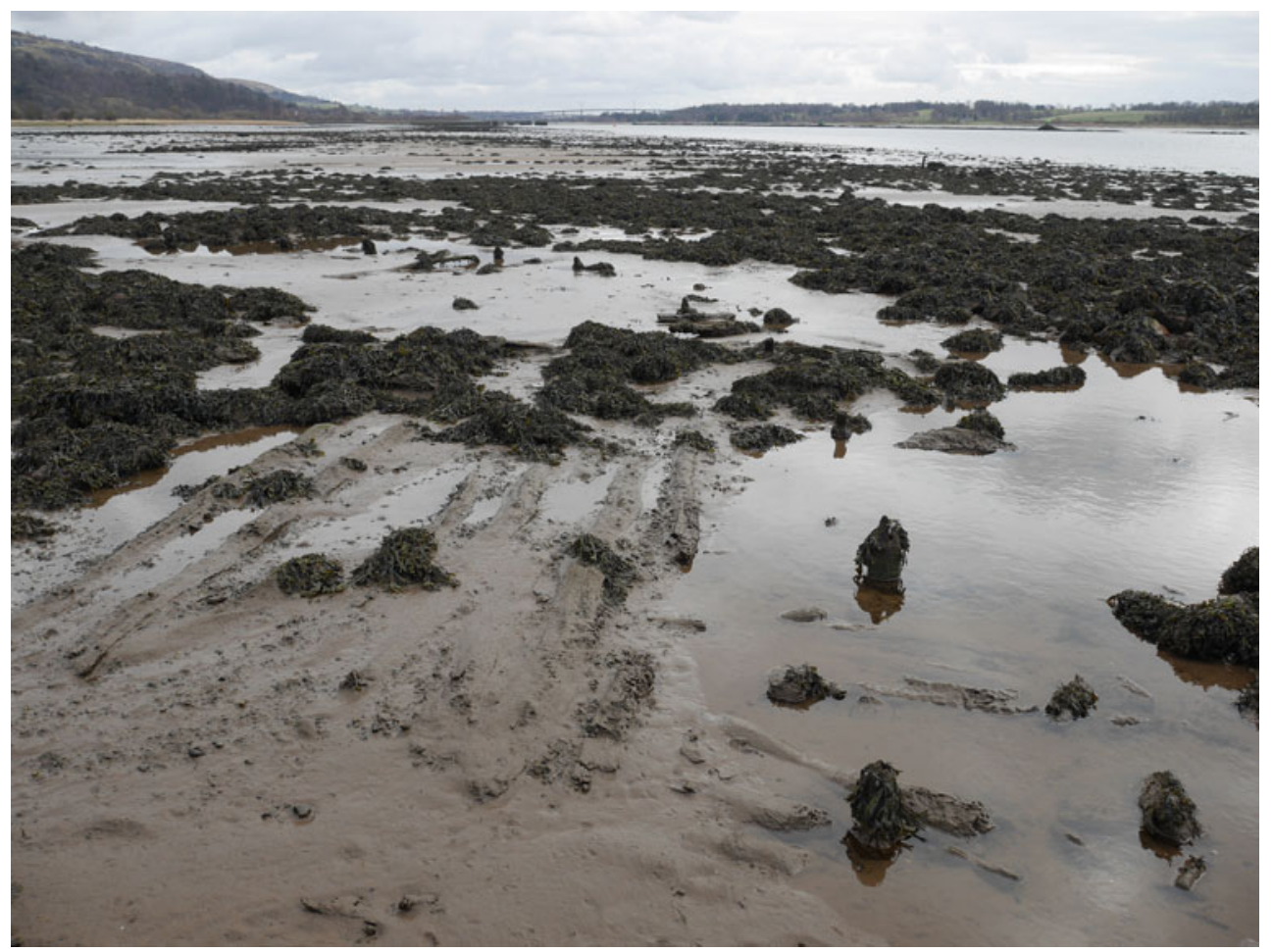

Figure 3. Dumbuck crannog. The three horizontal timbers were sampled from the exposed floor in the lower right-hand side quadrant of the photograph. To the right of the sampled floor, a section of the circle of upright piles is also visible.

(c) Crown Copyright Historic Environment Scotland.

circular horizontal feature built in alder (Figures 2 and 3). The site also included a dock-like feature that contained a canoe when first excavated in 1888-89 (Bruce, 1900). In its current state, the estuarine muds covering the timber components are mobile and eroding, with a number of timbers having been exposed since Hale's surveys in the 1990s. The second of the two sites, the Erskine Bridge crannog, is more complex. Unlike Dumbuck, it has never been subject to archaeological excavation, nor is its structure as clear. The site of the Erskine Bridge crannog consists of three main components: a semi-circular arrangement of timbers apparent in the eastern and north-eastern sections of the site, an irregular stone mound to the north-west, and possible covered deposits in the remainder of the site (Figures 4 and 5). Given our knowledge of the other sites, the interpretation that is most plausible for the time being is that the Erskine Bridge crannog was first constructed as a circular structure similar to the Dumbuck and Langbank East crannogs, then abandoned, leading to its transformation into a stony mound. Later, at some point before antiquarian records were made, the mound would have been broken up, leading to the formation of the irregular stone feature on the north-western side of the site.

Before the start of the research described here, the Dumbuck and Erskine Bridge crannogs were dated by four radiocarbon determinations each (online Supplementary Table 1). The samples from Dumbuck were collected during the 1999-2001 


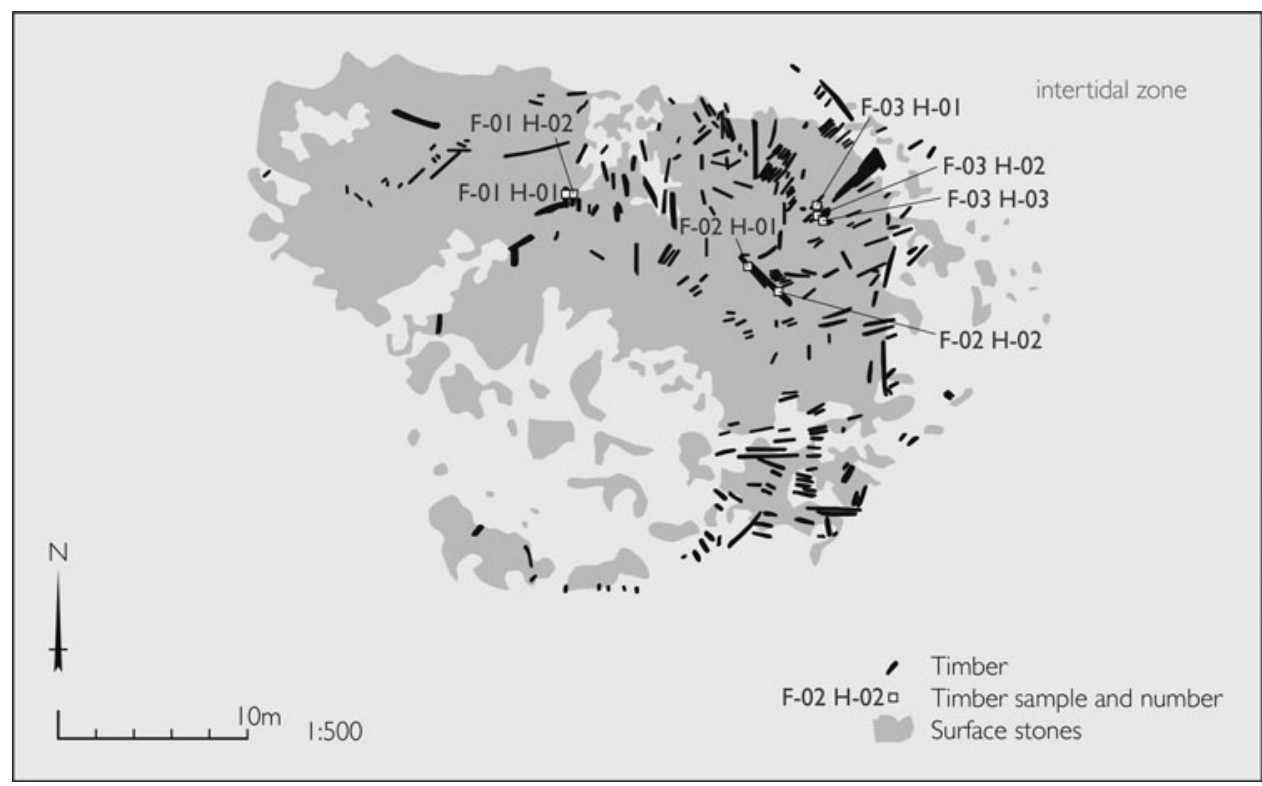

Figure 4. Plan of the Erskine Bridge crannog with the sampled timbers highlighted. (C) Crown Copyright Historic Environment Scotland.

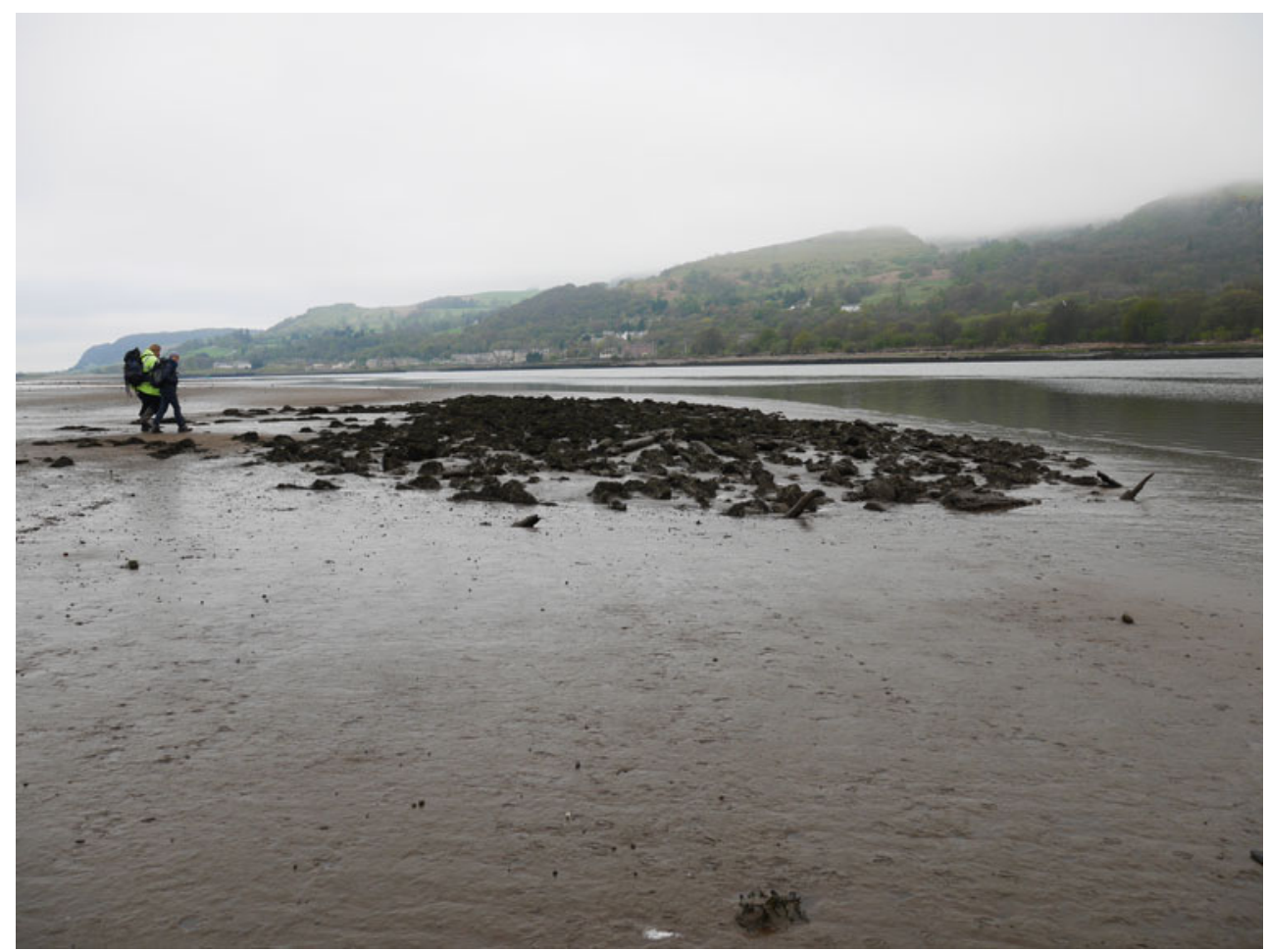

Figure 5. Erskine Bridge crannog.

(C) Historic Crown Copyright Environment Scotland. 
excavations and include material from the outer rings of two alder horizontals, and the outermost hardwood rings of the two oak posts. All samples calibrated to between about $200 \mathrm{cal} \mathrm{BC}$ and cal AD 200. The material from the Erskine Bridge crannog includes determinations on three alder horizontals and an oak post calibrated to a period from just after $400 \mathrm{cal} \mathrm{BC}$ to about cal AD 200. What is interesting about these dates is their scatter within the sites; while the calibrated date ranges between the two locations overlap, there is a degree of internal divergence within each site. This is clearer at the Erskine Bridge crannog, where two of the dates are more recent than the other two. There are two conceivable reasons for this:

(1) some of the timbers have been reused, or

(2) the marine crannogs were long lived.

The latter interpretation is difficult to conceive on the grounds of the shallow nature of the sites, making timber re-use the more plausible interpretation and setting up the case for accepting the more recent dates. Nevertheless, this is only an assumption rooted in an assessment of sites that are either unexcavated (Langbank West), excavated to antiquarian rather than modern standards (Langbank East and Erskine Bridge crannogs), or subject only to limited exposures in small trenches combined with an earlier antiquarian excavation (Dumbuck).

The broad scatter of the dates is important to understanding the context of the two locations: the legacy dating suggests that the two marine crannogs could have been contemporary, perhaps pointing to a period of more intensive activity within the Firth. Furthermore, a range of historic and prehistoric events occurred during the periods covered by the broad calibrated date ranges. Perhaps the bestknown of these is the activity on the
Antonine Wall in AD 142-162, when the extent of Roman control advanced temporarily northward from Hadrian's Wall to the Clyde-Forth isthmus (Harding, 2004). There are also other important events that took place over these centuries. These range from changes to the settlement pattern in the Scottish south-east in the decades following 200 cal BC (Hamilton, 2016), through more ephemeral trends, such as the apparent reduction in the intensity of wetland settlement beginning around the turn of the first millennia $\mathrm{BC}$ and $\mathrm{AD}$ (Crone, 2012), to specific historic events, such as Agricola's invasion of Scotland in AD 80 (Cunliffe, 2005) (Figure 6).

It is this broad range of possible historical contexts that makes resolving the site formation issues, hinted at by the legacy radiocarbon dates, so important. Without this, it is difficult to improve on the chronology of the construction of these sites, and without precise construction dates, it is impossible to resolve whether these sites are in any way linked to the many historical events that took place over the span of the calibrated ranges of the legacy dates. Hence, without a better chronology, the contextual analysis of the two sites remains limited.

\section{Dating Strategy}

The main question emerging from the study of the legacy dates from the Dumbuck and Erskine Bridge crannogs was whether these locations witnessed timber recycling in prehistory, were the product of multiple construction phases, or whether perhaps some other agency could be responsible for the apparent scatter of dates from each of these sites. To ascertain which one of these scenarios is most plausible, it becomes necessary to differentiate between timber re-use and 
OxCal v4.2.3 Bronk Ramsey (2013); r.5 IntCal13 atmospheric curve (Reimer et al 2013)

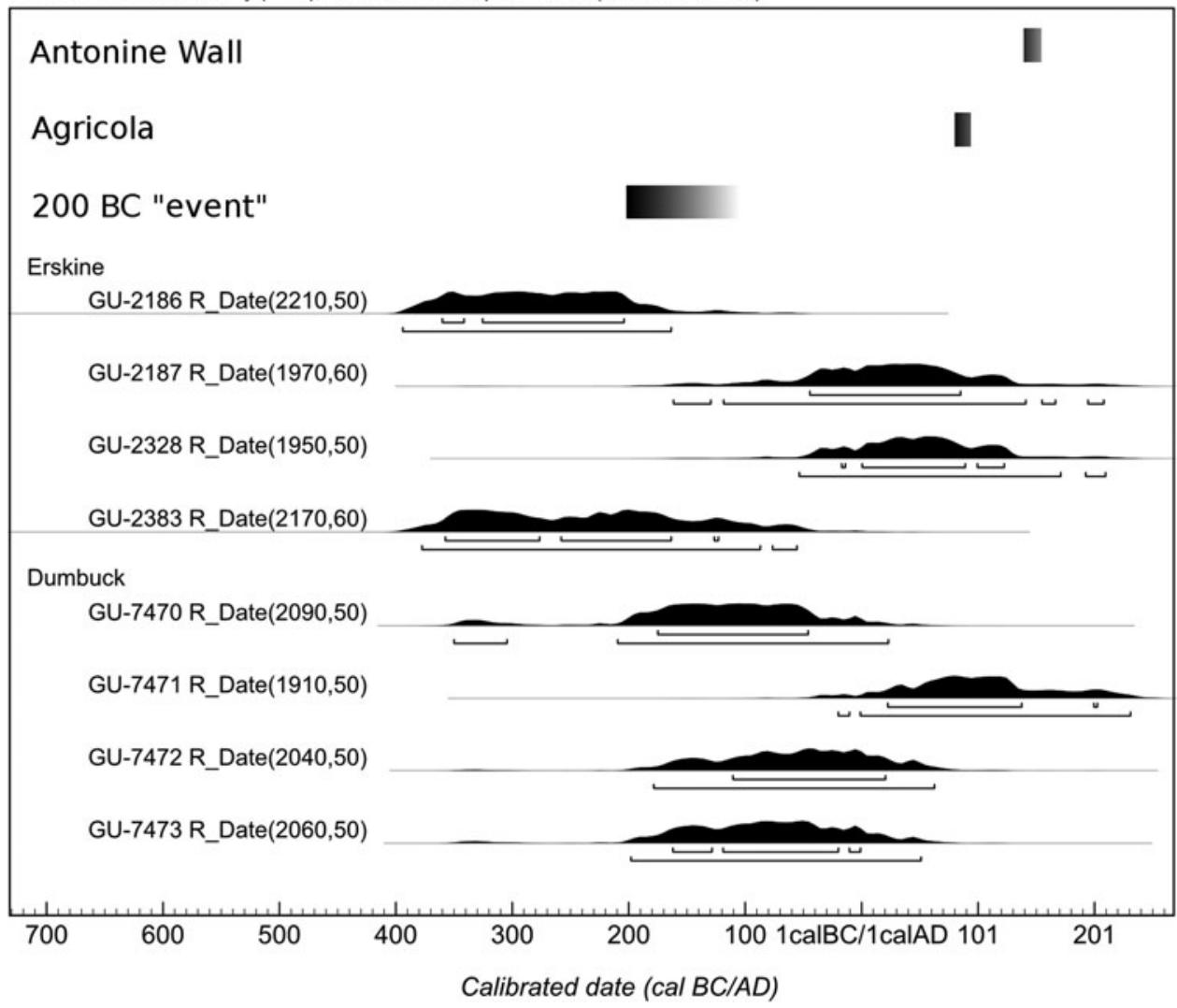

Figure 6. Legacy dates from the Dumbuck and Erskine Bridge crannogs alongside the estimated dates of events and processes that may have some relation to the structures in the intertidal zone of the Firth of Clyde.

structural reconstruction. The most straightforward way to achieve this is through a feature-oriented sampling approach wherein, rather than just collecting a range of timbers from across the site, several timbers are collected from discrete structural features. This sampling framework means that, if the timbers from within a feature show different dates, it becomes reasonable to argue for timber re-use, while age differences between features strengthen the case for multiple phases of structural activity.

A feature-oriented sampling design requires good dating precision: consider the legacy dates GU-7472 and GU-7473 (Figure 6). Their partial overlap and broad calibrated date ranges mean that, even though they are very similar to one another, there could have been a difference of 200 years between these samples. In principle, in a situation like this, it would be preferential to use dendrochronological dating, which can provide precision to the level of a single year. However, this is impossible in the context of the Clyde crannogs, because not only is the number of timbers that can be retrieved without destroying the sites limited, but also the majority of the samples collected would be alder-a species whose dendrochronology is still in its infancy (Crone, 2014). Moreover, the few oak timbers that are present tend to be short-lived and subject to strong local signals, which makes it 
difficult to obtain reliable dendrochronological dates (Crone, 1988, 1998).

Nevertheless, the limitations faced by dendrochronology in this context can be bypassed by using the radiocarbon wigglematch dating technique (Fergusson et al., 1966; Bronk Ramsey et al., 2001). This technique relies on taking multiple subsamples through the rings structure and dating these to cover the period over which the wood formed. Cellulose within this wood is laid down in the year that the tree-ring forms and does not exchange its carbon atoms afterwards. Hence, it becomes possible to reproduce a small section of the past radiocarbon trend and match it to the internationally ratified calibration curve, which, at the time of writing, is IntCal13 (Reimer et al., 2013). Since the number of places where the set of measurements can fit the calibration curve will be limited, wiggle-match dating allows much better calibrated precision to be achieved than would be possible through individual radiocarbon dates. Wiggle-match dating in its basic form is applicable to all archaeological timbers that display unambiguous annual growth rings and that have lived for long enough to make a meaningful fit to the calibration curve. For example, had the sample put on only ten growth rings, then it would be of little use to try to wiggle-match it to a section of the calibration curve based on decadal sample blocks.

\section{Methodology}

Producing the analytical results discussed in the remainder of this article required a series of steps from sample collection to AMS measurement. The timbers were collected from deposits exposed by erosion using a hand saw and transported to Scottish Universities Environmental Research Centre (SUERC). There they were cut into $2-3 \mathrm{~cm}$ thick transverse slices with a clean hand saw. Next, the surfaces of the transverse slices were prepared with an acetonecleaned razor blade to improve the visibility of individual rings and to remove any contaminants from the surfaces. After counting the tree-rings and, where possible, recording their widths, the transverse slices were subsampled into decadal blocks and dried out before further processing and measurement. Ten-year sample blocks were chosen as the majority of the underpinning calibration data in the first millennia $\mathrm{BC}$ and $\mathrm{AD}$ are also decadal. None of the timbers discussed in this study was consolidated in any way (e.g. with polyethylene glycol).

The decadal blocks were sliced very finely and pre-treated using the cellulose-extraction protocol modified from that described by Dunbar et al. (2016). This consisted of solvent extraction, bleaching with hypochlorite solution, and acid-alkali-acid steps. Solvent extraction involves refluxing the sample in a Soxhlet apparatus using a 2:1 mixture of chloroform and ethanol, followed by a second Soxhlet extraction using ethanol, and concluding with multiple water washes on a hot plate to ensure the removal of any residual ethanol. After the final water step, the samples were dried, re-weighed, and put into acidified sodium chlorite $(3 \mathrm{~g} \mathrm{NaCl} 2 \mathrm{O}$ per $1.2 \mathrm{ml} \mathrm{HCl}$ dissolved in $400 \mathrm{ml}$ water). This procedure removes lignin, some of which may have contained carbon atoms from photosynthesis that took place after the formation of the tree-ring (Taylor et al., 2002). The third step involved heating the sample on a hot plate in acid $(0.5 \mathrm{M} \mathrm{HCl})$, then alkali $(0.5 \mathrm{M} \mathrm{NaOH})$ and finally, acid again $(0.5 \mathrm{M} \mathrm{HCl})$. The first acid step helps to remove acid soluble contaminants, the alkali step removes alkali-soluble contaminants, as well as some of the less stable forms of cellulose, and the final acid step neutralizes the alkali to ensure that the sample does not absorb atmospheric $\mathrm{CO}_{2}$. An alteration to the method published by 
Dunbar et al. (2016), the bleaching and the acid-alkali-acid steps were repeated. At the end of the process, the sample was washed in ultra-pure water and dried. The pretreated samples were then combusted using the method of Vandeputte et al. (1996). The resultant $\mathrm{CO}_{2}$ was cryogenically purified and reduced to graphite using the method of Slota et al. (1987), before pressing into aluminium cathodes for ${ }^{14} \mathrm{C}$ measurement at the SUERC AMS facility (Naysmith et al., 2010). Further aliquots of the gases were measured by isotope ratio mass spectrometry for $\delta^{13} \mathrm{C}$ to allow fractionation corrections to be made to the ${ }^{14} \mathrm{C}$ measurements.

All the Bayesian analyses were conducted in OxCal 4.2 (Bronk Ramsey, 2009a), using the IntCal13 radiocarbon calibration curve (Reimer et al., 2013). Note that since 2004 the internationally ratified calibration curves are no longer lines joining the points set by the underpinning calibration data, but statistical models estimating a most plausible path for a random walk through the calibration data (Blackwell et al., 2006). When conducting the Bayesian analysis, $\mathrm{OxCal}$ calculates agreement indices that describe how well the proposed model fits the data. For most models, these indices should be greater than 60 per cent, but in the case of the wiggle-match agreement index $\left(\mathrm{A}_{\text {combine }}\right)$, this value depends on the number of radiocarbon determinations per timber. In the case of wiggle-matches, the $\chi^{2}$ test statistic is also calculated to estimate the quality of fit between the unknown samples and the radiocarbon curve.

\section{Dumbuck}

\section{Sampling}

Piotr Jacobsson and Alex Hale sampled five timbers from the Dumbuck crannog: two vertical oak posts (P-01 and P-02) and three alder horizontals (HT-001, HT-002, and HT-003). The first oak post, $\mathrm{P}-01$, had fifty-nine growth rings, and the second, P-02, had fifty-three growth rings. The sapwood in both cases was very decayed and eaten by shipworm (Teredo navalis), but the bark edge was retained and the individual rings could be identified, albeit with difficulty. The heartwood of the oaks was well preserved and free from shipworm attack. The three horizontal timbers, HT-001, HT-002, and HT-003 had fifty-four, thirty-seven, and twenty-nine growth rings respectively, retained bark edge, and suffered to a minor extent from shipworm burrowing, but were altogether well preserved. From these timbers, contiguous decadal sample blocks were collected, prepared, and submitted for AMS measurement (online Supplementary Figure 1).

\section{Wiggle-match dates}

The five wiggle-match dates from Dumbuck $^{2}$ were for the most part almost identical to one another (online Supplementary Figures 2-6; Supplementary Tables 2 and 3). They all date to between $45 \mathrm{cal} \mathrm{BC}$ and cal $\mathrm{AD} 65$, with individual agreement indices and $\chi^{2}$ test statistics all within acceptable ranges. One recurrent theme within the wiggle-matches was that the third or fourth decades from the bark edge appear to be older than the corresponding value of the calibration curve at this point $(c .5 \mathrm{cal} \mathrm{BC})$. This may be because the slight rise in the calibration curve at this point is over-smoothed by the algorithm that was used to construct the curve, as suggested by the divergence of the underpinning calibration measure-

\footnotetext{
2 The data from Dumbuck and Erskine Bridge crannogs was included in Jacobsson's unpublished PhD dissertation (2015).
} 
ments from the curve estimate (online Supplementary Figure 7), and the fact that the systematic offset at Dumbuck only applies to the third and fourth decades, across different species of wood, with no similar offsets affecting other rings. While this divergence of the calibration curve from the underpinning measurements would have a minimal effect on most routine ${ }^{14} \mathrm{C}$ applications, in the case of wiggle-match dating, such minor offsets can have an adverse effect on short sequences. This was the case for all three horizontal timbers sampled at Dumbuck, and the problematic measurements were removed from the wiggle-matches to mitigate the adverse effects. They have been retained in the wiggle-matches of the oak timbers within which, due to the greater length of the samples, they had little impact on the model. Note that similar (and larger) divergences are known from several more precise studies on the Holocene calibration curve (e.g. Wacker et al., 2009; Güttler et al., 2013; Manning et al., 2014). The exact nature of these offsets appears to vary from case to case and is the subject of ongoing research.

\section{Site model}

The five wiggle-match dates and the four legacy radiocarbon dates have been put into a bounded uniform phase model (Buck et al., 1992). This kind of model makes no informed assumptions about the relationships between the samples and only estimates the onset and termination of the deposition process responsible for the presence of the samples in the first place. The model was queried for an estimate of the most recent felling date for a timber within it, which is taken to be a plausible proxy for the actual construction date. Seen from this perspective, the construction date is estimated to cal $A D$ 5-55 (95.4 per cent probability; Dumbuck construction Last) (Figure 7 and online Supplementary Figure 8). The model suffers from a low agreement index $\left(A_{\text {model }}=20.9\right.$ per cent $)$, which can be traced to the presence of two measurements (SUERC-60783 and SUERC60791) from oak posts P-01 and P-02 that show a divergence towards older than expected ${ }^{14} \mathrm{C}$ values (as discussed in the previous sub-section), as well as the effects

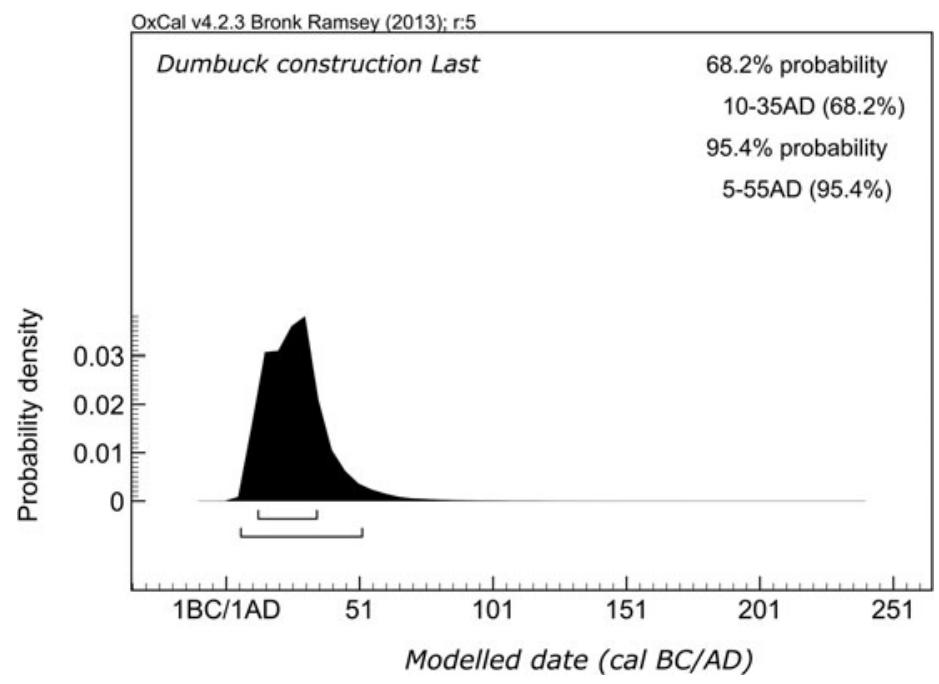

Figure 7. Estimate of the construction date of the Dumbuck crannog, based on the most recent plausible felling date among the dated timbers dated. 
of two of the legacy dates: GU-7470 and GU-7471. The first of these dates, GU7470 has a noticeable deflection towards older ages. This might be an old wood effect; but it is also possible that these rings, collected from the outermost rings of oak heartwood, may date to the suspected 5 cal BC deflection, as was the case for the other two oak timbers from the site. The second determination in question, GU-7471, includes sections of the construction estimate within its 95.4 per cent calibrated date range and so the difference can be attributed to measurement uncertainty. In any case, the presence or absence of these measurements does little to affect the estimate of the construction date and both are retained in the final model. The model itself was re-run using alternate outlier specifications allowing for stockpiling of timbers ahead of construction (using the Zero_Boundary(); and Tau_Boundary (); commands). These alternate specifications had no noticeable impact on the parameters of interest, such as the construction date of the Dumbuck crannog.

\section{Erskine Bridge Crannog}

\section{Sampling}

At the Erskine Bridge crannog, four horizontals from two potential structural features (Features 01 and 02) were sampled by Piotr Jacobsson and Alex Hale, alongside three smaller timbers from what appeared to be an eroding floor in the north-eastern corner of the site (Feature 03) (Figure 3, online Supplementary Figures 9-11). The first pair of associated timbers, F-01 H-01 and F-01 H-02, were substantial alder logs, the first of which had over 100 countable rings while the other had eighty-seven. The second pair of associated timbers, F-02 H01 and F-02 H-02 also consisted of two large alder logs, the first of which had ninety-one countable rings while the second had seventy-six. All four timbers lacked bark edge; however, both observations in the field and the large ring counts suggest that the final growth ring was at most within twenty growth years of the outermost surviving growth ring on each of the samples. In other words, the offset between the wiggle-match date and the actual felling date would not exceed twenty years. The three smaller timbers, F-03 H01, F-03 H-02, and F-03 H-03, come from what appeared to have been an eroding floor. They all contained fewer than twenty rings and retained the bark edge. Contiguous or overlapping samples were selected from the small timbers of F03, but the long spans of the F-01 and F-02 sequences meant that only partial sampling was necessary. Online Supplementary Table 4 and online Supplementary Figure 12 contain the details of the decadal blocks chosen, as well as the results of the individual measurements. Due to the very short length of the F-03 H-03 sequence, it was only possible to sample a single decadal block, hence this sample is included in the model as an individual radiocarbon determination.

\section{Wiggle-match dates}

The main challenge for the construction of the wiggle-matches for the Erskine Bridge crannog was the decayed state of the wood, most pronounced in the large timbers, F-01 and F-02. During this and other wigglematch dating studies of wetland sites from south-western Scotland, it became apparent that the outermost and the more decayed rings can produce radiocarbon determinations that shift towards greater ages (online Supplementary Figure 13). While the origin of this phenomenon remains speculative, and further research is necessary to identify the causal factors, a similar shift to greater radiocarbon ages appears to be present in 
samples from the Erskine Bridge crannog. Therefore, building the wiggle-matches to date the site requires some means of overcoming this technical difficulty. One way of achieving this is to use an outlier model when estimating the wiggle-match dates. There are a range of outlier models that can be implemented in OxCal (Bronk Ramsey, 2009b); but the one applicable in the current situation is the ' $\mathrm{r}$ ' model, which estimates a probability distribution of the offset and adds it to the radiocarbon scale probability distribution of the sample (i.e. the radiocarbon age measured in ${ }^{14} \mathrm{C}$ years $\mathrm{BP}$ ). The outlier model specification was Outlier_ Model ('General', U(0, 400), 0, ' $r$ '); the key parameters of interest in the specification are the ' $\mathrm{r}$ ' and the $\mathrm{U}(0,400)$. The ' $r$ ' specifies the type of outlier being used, and $\mathrm{U}(0,400)$ is a prior probability distribution on the magnitude of the offsets stating that, prior to the model estimation, the offset is believed to be anything between 0 and $400{ }^{14} \mathrm{C}$ years.

The probability that any given measurement should be subject to this outlier model is based on whether the sample was exposed to environmental conditions, either through location on the outer edge of the timber, or through decay and shipworm attack. In practice, this meant attributing a prior probability of a sample being an outlier to all the outermost decadal blocks and the innermost ones (as the pith suffered the worst of the decay). In the case of the timber F-01 H-02, this probability was applied throughout as the timber suffered from very extensive decay and shipworm burrowing throughout. The actual prior of any indicated sample being an outlier was set to 0.5 (\{Outlier(0.5);\}). This choice was motivated by the way that the posterior probability of these parameters works in the model: it scales down the effects of the outlier model, allowing for variability in how much the samples in question are affected. The results of the wiggle-matches after the application of the outlier model are presented in the online supplementary material (Supplementary Figures 14-19; Supplementary Tables 4 and 5). The reliability of these results is supported by their convergence with a range of alternative outlier model specifications, as well as the results of the wiggle-matches without the outlier specification (online Supplementary Table 6).

\section{Site model}

The site model, using the same uniform bound phase assumption as Dumbuck, included all the new data and two of the legacy dates (online Supplementary Figure 20). The other two legacy dates, GU2187 and GU-2328 are both much more recent than the remainder of the evidence, which may be due to the timbers deriving from some secondary, more ephemeral activity on the site, perhaps associated with the break-up of the original crannog mound. However, as it is difficult to determine where in the structure they came from, it is impossible to evaluate the reality of such a supposition. As the four large timbers lacked preserved bark edge, their final date estimates were shifted by between zero and twenty years to allow for the missing rings (see Sampling section above).

The construction event is estimated to 330-215 cal BC (95.4 per cent probability; Erskine construction Last) (Figure 8). The duration over which the timbers in question were felled was 35-160 years (95.4 per cent probability; Erskine felling Span). The ' $r$ ' outlier model does not revise the agreement indices of the individual determinations and so the model agreement index in this case might not be representative of the actual model reliability. To avoid this issue, the model was re-run using .prior files, which isolated the results of individual wiggle-matches, thus 


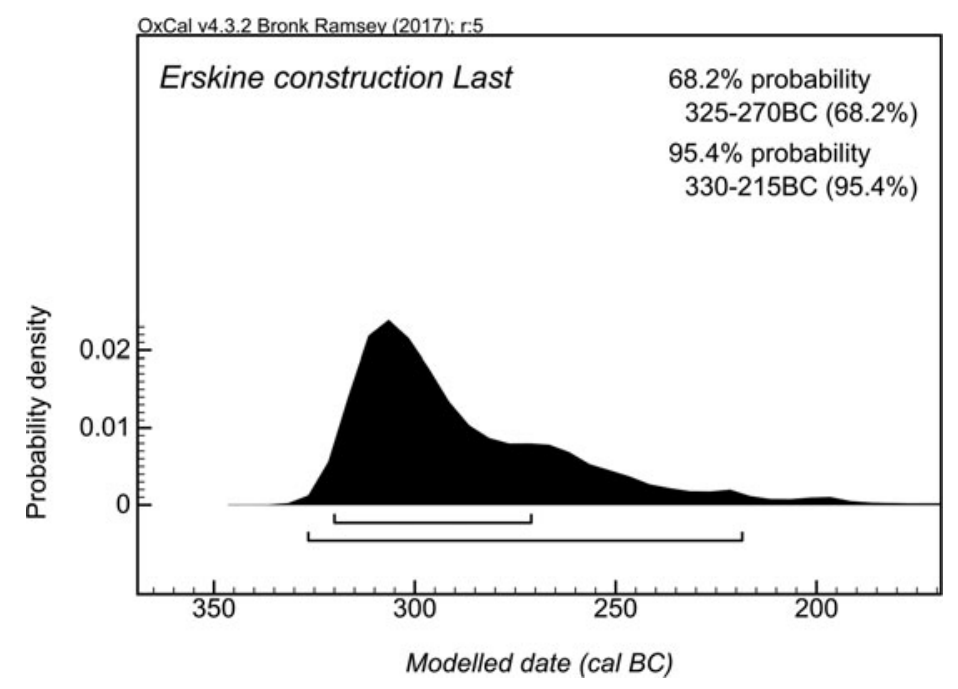

Figure 8. Estimate of the construction date of the Erskine Bridge crannog, based on the most recent plausible felling date among the timbers dated.

bypassing the problem of non-updated individual agreement indices. Carried out this way, the model agreement is good $\left(\mathrm{A}_{\text {model }}=80.5\right.$ per cent $)$. The results, as they stand at present, indicate some age variability within the Erskine Bridge crannog timbers, which, in turn, suggests that some may have been re-used from earlier structures, something possibly also encountered at Black Loch of Myrton and Cults Loch 3, two other Scottish earlier Iron Age wetland sites (Jacobsson, 2015).

\section{Discussion}

The results of the wiggle-match dating provide solid evidence that the two crannogs were built several generations apart. This alone has some basic implications for interpreting the two sites. For one thing, it casts considerable doubt on the notion that the four marine crannogs in the Firth of Clyde are the remains of a single flurry of activity at the terrestrial/maritime interface, making it difficult to postulate that the group of sites is a sign of some socio-political event.
Further, the time elapsed between the construction of the two sites, 370-235 years (95.4 per cent probability; Dumbuck-Erskine Bridge Difference) (Figure 9) casts doubts on whether the relationships between the marine crannogs, the Firth, and the communities who built them were the same in both cases. It is conceivable that, in an unregulated estuary, structures of similar function would have to be rebuilt at different locations as the water course changed. However, given the magnitude of the gap between the activity at the Dumbuck and Erskine crannogs, it is possible that the two sites were built for different purposes. Of course, dating programmes with similar levels of precision on the other two undated sites, Langbank East and West, may further enhance or even change this picture.

The difference between the construction dates of the Erskine Bridge and Dumbuck crannogs also highlights a difference in the surroundings of the two sites. The hinterland of the Erskine Bridge crannog (and the two Langbank crannogs) consists of low rolling hills, without many steep gradients, that stretch for many miles. At the 


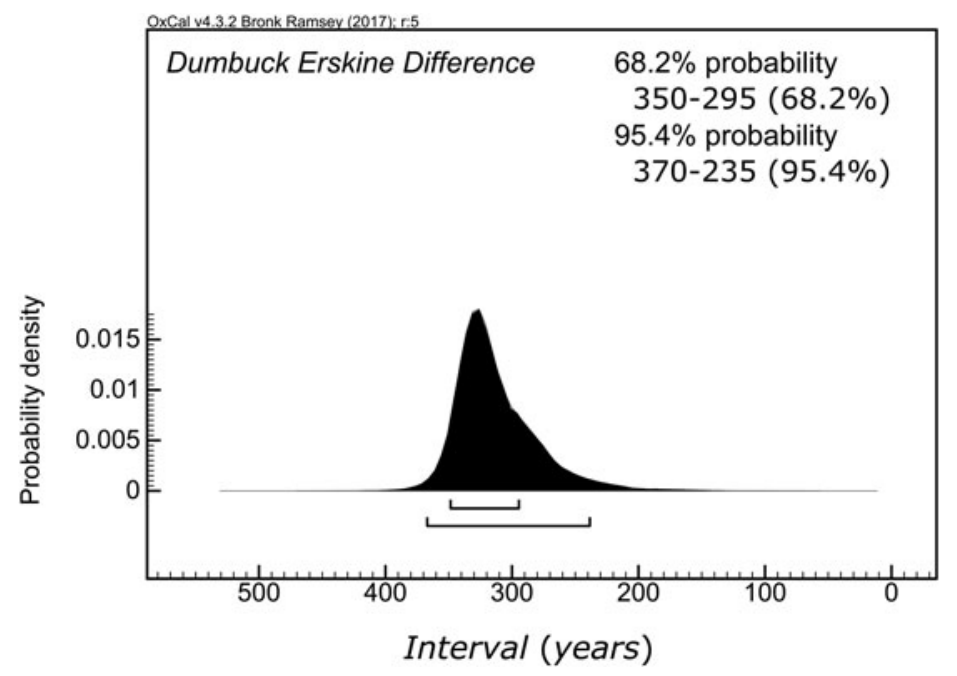

Figure 9. Difference between the estimated construction dates for the Dumbuck and Erskine Bridge crannogs.

Dumbuck crannog the situation is very different, with the hinterland consisting of a narrow strip of flat land, before a steep rise onto the more substantial hills, from whose peaks clear views extend over not only the majority of the Firth of Clyde, but also to the north over Loch Lomond. Therefore, the two crannogs would have been located in different ecotones. It is also possible that this choice may have been deliberate; only $2 \mathrm{~km}$ to the west of the Dumbuck crannog, the hinterland changes from a high plateau to the low-lying valley of the River Leven. Hence, conditions similar to those found on the southern shore of the estuary could also be found on its northern shore. Nevertheless, the close proximity of these sites also means that the different hinterlands could be exploited from both sites. Further environmental studies, both onand off-site, must be conducted before reaching any conclusions on the subject. Still, this difference in choice of location constitutes another difference between the Erskine Bridge and Dumbuck crannogs that may or may not have been affected by the different historic contexts of the two crannogs.
The immediate geographic context of the two sites also includes the two marine crannogs at Langbank, another site at Old Kilpatrick, mentioned in the nineteenth century and confirmed by more recent surveys (Hale, 2004), as well as a range of terrestrial sites which could be reached within a few hours' walk (Figure 1). While the two remaining crannogs are, for the most part, undated, save for a bone comb from Langbank East that has been typologically assigned to the first century $\mathrm{AD}$ (MacGregor, 1976), there is some limited dating evidence from the terrestrial sites, which suggests some possible overlap with the two marine crannogs. One example is the date (SUERC-19607, $2135 \pm 30{ }^{14} \mathrm{C}$ years BP, 355-50 cal BC) from the infill of the ditch of the palisaded enclosure at Mar Hall, just $500 \mathrm{~m}$ south of the Erskine Bridge crannog (Cavers et al., 2012), which indicates that this infill may have been contemporary with the construction of the crannog. Nevertheless, further dating of the material from the enclosure is necessary to confirm the chronological overlap between the two events. A similar situation occurs at the Dumbuck crannog, 
where the construction date of cal AD 555, discussed above, overlaps with the period of what the excavator believes to have been the final spate of Iron Age activity atop Sheep Hill (MacKie, 2015), a hillfort that overlooks the Dumbuck crannog. Again, the dating evidence from the terrestrial site is still too limited to confirm such a correlation. It is through these and similar case studies that it becomes clear that further work is required to constrain the chronology of the remaining sites in and around the Firth, but also that such improvement can be attained.

There is, however, one site in the vicinity of the Clyde crannogs for which the chronological ambiguity and association has been resolved with this study, that is their relationship to the terminus of the Antonine Wall, dated to the mid-second century AD. Based on the Antonine Wall's spatial proximity to the Erskine Bridge crannog, as well as the legacy dates from the sites, the notion emerged that the construction of the Erskine Bridge crannog could have somehow related to the presence of the Antonine Wall (see Sands \& Hale, 2002). This followed a broader belief that crannog sites were elite households that, in the period of Roman activity in northern Britain, would have been involved in a client economy with the invaders (Hunter, 1994). Although the results from the Erskine Bridge crannog alone are insufficient either to confirm or reject the broader notion, they do demonstrate that the construction of this particular site could not have been in any way motivated by the Roman presence in Scotland, as there is a gap of over 250 years between the crannog and the construction of the Antonine Wall (Figure 10). This clarification of the relationship between the Erskine Bridge crannog and the Antonine Wall illustrates the crucial importance of establishing the chronological relationship between nearby sites before proposing any interpretations based on their proximity.

Although it is very improbable that the two dated Clyde crannogs were affected in any direct way by the Roman presence in Scotland, they would still have been rooted in the broader (pre)historic contexts of the Iron Age, and it is perhaps here that the importance of the dating for interpretation becomes clearest. The key point to note about the construction dates is that they place the two structures in different periods of the Scottish Iron Age. Erskine Bridge crannog, with its fourthcentury cal $\mathrm{BC}$ date, is closer to such events as the final stages of structural activity at Cults Loch 3 (Cavers \& Crone, forthcoming) and perhaps other artificial islands in

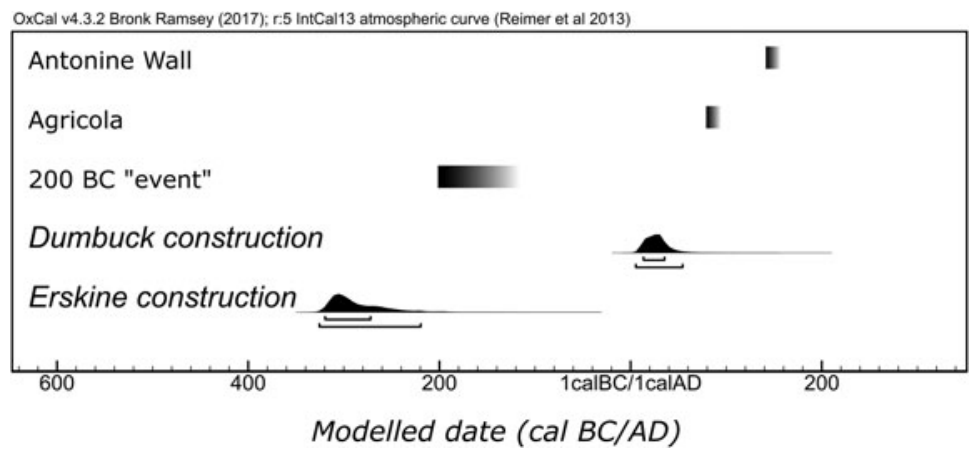

Figure 10. The new construction estimates for the Dumbuck and Erskine Bridge crannogs visualized against the events presented in Figure 6. 
the Scottish south-west. Between the construction of the Erskine Bridge and Dumbuck crannogs there is the watershed period around $200 \mathrm{cal} \mathrm{BC}$. During this period, small rectilinear enclosures first appeared in the Scottish south-east (Hamilton, 2016); and it is also possible that the peak in the construction of monumental Atlantic roundhouses (known as brochs) also took place then (Henderson, 2007). The period that follows this watershed can, thus, be expected to be characterized by altered political and economic relationships within the local communities, even though there might be a continuity of some aspects of material practice. Furthermore, by the turn of the millennium, there are further changes to the settlement pattern throughout Scotland. The most notable is the decreasing amount of evidence for structural activity on wetland sites. If these observations prove true, then the motivation behind the construction and the role played by the Dumbuck crannog would have been different from the incentive to build the Erskine Bridge crannog; hence, whatever the specific function we wish to attribute to these locations, contextual awareness demands that we do not consider them as identical, even though they may have formed part of the same tradition.

\section{Conclusions}

This article discussed the radiocarbon wiggle-match dating of two intertidal platforms in the Firth of Clyde: the Dumbuck and Erskine Bridge crannogs. Much of their interpretation hinges on their precise dating, for without it, one cannot ascribe them to an accurate chrono-historical context. The legacy radiocarbon dates from both sites indicated that they might have been contemporary, but they also highlighted that some of the timbers could have been re-used. This meant that the sampling strategy employed had to take this risk into account and mitigate it, something that was achieved through the feature-oriented sampling of timbers. The results from the two sites put their construction almost three centuries apart at the very minimum, in the fourth century $\mathrm{BC}$, and in the first half of the first century AD. This means that some of the earlier interpretations, relating these sites to the activity on the nearby Antonine Wall, can no longer be substantiated. Furthermore, with the new dating placing the two sites in what may be very different historical contexts, we must now explore whether they have much in common besides their form.

\section{ACKNOWLEDGEMENTs}

We would like to thank Historic Scotland (now Historic Environment Scotland) for funding the radiocarbon determinations; SUERC ${ }^{14} \mathrm{C}$ laboratory and AMS staff for help with sample pre-treatment, graphitization, and measurement; Georgina Brown (Historic Environment Scotland) for help with drafting Figures 1-3. Piotr Jacobsson would like to acknowledge the Royal Society of Edinburgh Caledonian Research Fund Scholarship. Alex Hale would like to acknowledge fieldwork leave and support from the Royal Commission on the Ancient and Historical Monuments of Scotland (RCAHMS, now Historic Environment Scotland). We would also like to thank Historic Environment Scotland for funding the open access publication of this paper.

\section{REFERENCES}

Blackwell, P.G., Buck, C.E. \& Reimer, P.J. 2006. Important Features of the New Radiocarbon Calibration Curves. Quaternary Science Reviews, 25: 408-12. 
Bronk Ramsey, C. 2009a. Bayesian Analysis of Radiocarbon Dates. Radiocarbon, 51: 337-60.

Bronk Ramsey, C. 2009b. Dealing with Outliers and Offsets in Radiocarbon Dating. Radiocarbon, 51: 1023-45.

Bronk Ramsey, C., van der Plicht, J. \& Weninger, B. 2001. 'Wiggle Matching' Radiocarbon Dates. Radiocarbon, 43: 38189.

Bruce, J. 1900. Notes of the Discovery and Exploration of a Pile Structure on the North Bank of the River Clyde, East from Dumbarton Rock. Proceedings of the Society of Antiquaries of Scotland, 34: 437-62.

Bruce, J. 1908. Report and Investigations upon the Langbank Pile Dwelling. Transactions of the Glasgow Archaeological Society, New Series, 5: 282-89.

Buck, C.E., Litton, C.D. \& Smith, A.F.M. 1992. Calibration of Radiocarbon Results Pertaining to Related Archaeological Events. Journal of Archaeological Science, 19: 497-512.

Cavers, G. \& Crone, B.A. forthcoming. A Lake Dwelling in its Landscape; Iron Age Settlement at Cults Loch, Castle Kennedy, Dumfries and Galloway. Edinburgh: Society of Antiquaries of Scotland.

Cavers, G., Clements, V. \& Lynchehaun, S. 2012. Excavation of a Prehistoric Enclosure at Mar Hall, Bishopton, Renfrewshire. Scottish Archaeological Journal, 34-5: 117-35.

Crone, B.A. 1988. Dendrochronology and the Study of Crannogs (unpublished PhD dissertation, University of Sheffield).

Crone, B.A. 1998. The Development of an Early Historic Tree-Ring Chronology for Scotland. Proceedings of the Society of Antiquaries of Scotland, 128: 485-93.

Crone, B.A. 2012. Forging a Chronological Framework for Scottish Crannogs: The Radiocarbon and Dendrochronological Evidence. In: M.S. Midgley \& J. Sanders, eds. Lake Dwellings after Robert Munro. Proceedings from the Munro International Seminar: The Lake Dwellings of Europe, 22nd and 23rd October 2010, University of Edinburgh. Leiden: Sidestone Press, pp. 139-68.

Crone, B.A. 2014. Dendrochronological Studies of Alder (Alnus glutinosa) on Scottish Crannogs. Journal of Wetland Archaeology, 14: 22-33.

Cunliffe, B. 2005. Iron Age Communities in Britain: An Account of England, Scotland and Wales from the Seventh Century $B C$ until the Roman Conquest. London \& New York: Routledge.

Dixon, T.N. 1991. The History of Crannog Survey and Excavation in Scotland. International Journal of Nautical Archaeology, 20: 1-8.

Dunbar, E., Cook, G.T., Naysmith, P. \& Tripney, B.G. 2016. AMS ${ }^{14} \mathrm{C}$ Dating at the Scottish Universities Environmental Research Centre (SUERC) Radiocarbon Dating Laboratory. Radiocarbon, 58: 9-23.

Fergusson, C.W., Huber, B. \& Suess, H.E. 1966. Determination of the Age of Swiss Lake Dwellings as an Example of Dendrochronologically-Calibrated

Radiocarbon Dating. Zeitschrift für Naturforschung, 19(A): 1173-77.

Güttler, D., Wacker, L., Kromer, B., Friedrich, M. \& Synal, H.-A. 2013. Evidence of 11-Year Solar Cycles in Tree Rings from 1010 to 1110 AD: Progress on High Precision AMS Measurements. Nuclear Instruments and Methods in Physics Research Section B: Beam Interactions with Materials and Atoms, 294: 459-63.

Hale, A. 2000. Marine Crannogs: Previous Work and Recent Surveys. Proceedings of the Society of Antiquaries of Scotland, 130: 537-58.

Hale, A. 2004. Scottish Marine Crannogs. Oxford: Archaeopress.

Hale, A. \& Sands, R. 2005. Controversy on the Clyde: Archaeologists, Fakes and Forgeries: The Excavation of Dumbuck Crannog. Edinburgh: Royal Commission on the Ancient and Historical Monuments of Scotland.

Hamilton, D. 2016. Timing Transformation: The Application of Radiocarbon Dating and Bayesian Modelling to Produce Refined Chronologies for Later Prehistoric Settlements from the Tees to the Forth. In: R. Crellin, C. Fowler \& R. Tipping, eds. Prehistory without Borders: The Prehistoric Archaeology of Northeast England and Southeast Scotland. Oxford: Oxbow Books, pp. 224-43.

Harding, D.W. 2004. The Iron Age in Northern Britain: Celts and Romans, Natives and Invaders. London: Routledge.

Henderson, J.C. 2007. The Atlantic West in the Early Iron Age. In: C. Haselgrove \& R. Pope, eds. The Earlier Iron Age in 
Britain and on the Near Continent. Oxford: Oxbow Books, pp. 306-27.

Hunter, F. 1994. Dowlaton Loch Reconsidered. Transactions of the Dumfriesshire and Galloway Natural History and Antiquarian Society, 69: 53-72.

Jacobsson, P. 2015. Improving the ${ }^{14} \mathrm{C}$ dating of Scottish Crannogs (unpublished $\mathrm{PhD}$ dissertation, University of Glasgow).

MacGregor, M. 1976. Early Celtic Art in North Britain. Leicester: Leicester University Press.

MacKie, E.W. 2015. Excavations on Sheep Hill, West Dunbartonshire, 1966-69: A Late Bronze Age Timber-Framed Dun and a Small Iron Age Hillfort. Scottish Archaeological Journal, 36-37: 65-137.

Manning, S.W., Dee, M.W., Wild, E.M., Bronk Ramsey, C., Bandy, K., Creasman, P.P., et al., 2014. HighPrecision Dendro- ${ }^{14} \mathrm{C}$ Dating of Two Cedar Wood Sequences from First Intermediate Period and Middle Kingdom Egypt and a Small Regional ClimateRelated ${ }^{14} \mathrm{C}$ Divergence. Journal of Archaeological Science, 46: 401-16.

Miller, J. \& Ramsay, S., 2001. Botanical Analyses from Dumbuck Crannog, Firth of Clyde. Unpublished Report, Glasgow University Archaeological Research Division.

Naysmith, P., Cook, G.T., Freeman, S.P.H.T., Scott, E.M., Anderson, R., Xu, S., et al., 2010. ${ }^{14} \mathrm{C}$ AMS at SUERC: Improving QA Data with the 5MV Tandem and $250 \mathrm{kV}$ SSAMS. Radiocarbon, 52: 263-71.

Reimer, P.J., Bard, E., Bayliss, A., Warren Beck, J., Blackwell, P.G., Bronk Ramsey, C., et al., 2013. IntCal13 and Marine13 Radiocarbon Age Calibration Curves 0-50,000 Years cal BP. Radiocarbon, 55: 1869-87.

Sands, R. \& Hale, A. 2002. Evidence from Marine Crannogs of Later Prehistoric Use of the Firth of Clyde. Journal of Wetland Archaeology, 1: 41-54.

Slota, P.J., Jull, A.J.T., Linick, T.W. \& Toolin, L.J. 1987. Preparation of Small Samples for ${ }^{14} \mathrm{C}$ Accelerator Targets by Catalytic Reduction of CO. Radiocarbon, 29: 303-06.

Taylor, A.M., Gartner, B.L. \& Morrell, J.J. 2002. Heartwood Formation and Natural Durability: A Review. Wood and Fiber Science, 34: 587-611.

Vandeputte, K., Moens, L. \& Dams, R., 1996. Improved Sealed-Tube Combustion of
Organic Samples to $\mathrm{CO}_{2}$ for Stable Carbon Isotope Analysis, Radiocarbon Dating and Percent Carbon Determinations. Analytical Letters, 29: 2761-73.

Wacker, L., Nemec, M., Friedrich, M., Kromer, B., Hajdas, I. \& Synal, H.-A. 2009. Is it Time for a New Calibration Curve? Partial Re-Evaluation of the IntCal09 Radiocarbon Calibration Curve. Ion Beam Physics (ETH Zurich Labor für Ionenstrahlphysik, Annual Report) 2009: 48.

\section{Supplementary Material}

To view supplementary material for this article, please visit https://doi.org/10.1017/ eaa.2017.60.

\section{BiographicAl Notes}

Piotr Jacobsson is a Visiting Research Fellow at the British Institute in Amman. $\mathrm{He}$ obtained his undergraduate and MA degrees in archaeology at the University of Edinburgh. With a Royal Society of Edinburgh funded Caledonian Scholarship, he moved on to a $\mathrm{PhD}$ at the Scottish Universities Environmental Research Centre ${ }^{14} \mathrm{C}$ laboratory on the dating of wetland settlement in south-west Scotland, in which he outlined a dating strategy for these sites. Since 2015, he has been undertaking a Council for British Research in the Levant-funded review of Cypriot and south-west Asian published legacy dates to identify key technical challenges and conceptual issues in the ${ }^{14} \mathrm{C}$ dating of the Neolithic in the region.

Address: Scottish Universities Environmental Research Centre, Rankine Avenue, Scottish Enterprise Technology Park, East Kilbride G75 0QF, UK. [email: pt. jacobsson@gmail.com] 
Alex Hale is an Archaeology Projects Manager with Historic Environment Scotland. He obtained his $\mathrm{PhD}$ on the marine crannogs around the coast of Scotland from the University of Edinburgh in 2000. Since 2000, he has worked for RCAHMS as an Archaeological Investigator and continues to manage projects on aspects of the heritage of Scotland. Since 2011, he has increasingly undertaken collaborative research projects, many of which have been funded by the UK Arts and Humanities Research Council. Currently, he is managing a project that considers how to record historic and contemporary Scottish graffiti art.

Address: Historic Environment Scotland, Edinburgh, Scotland, John Sinclair House, 16 Bernard Terrace, Edinburgh EH8 9NX, UK. [email: alex.hale@rcahms. gov.uk]

Gordon Cook is Deputy Director of SUERC and head of the SUERC Radiocarbon Dating Laboratory. He received his undergraduate and $\mathrm{PhD}$ degrees at the University of Glasgow and went on to postdoctoral positions within the University, funded by the Agricultural Research Council and the Dounreay Nuclear Power and Development Establishment. $\mathrm{He}$ took charge of the radiocarbon laboratory in 1983, when it was based within the University of Glasgow. He moved to SUERC in 1986, setting up the laboratory again. $\mathrm{He}$ has published widely on aspects of radiocarbon dating, from measurement techniques to applications within archaeology, marine science, geology, and environmental science.

Address: Scottish Universities Environmental Research Centre, Rankine Avenue, Scottish Enterprise Technology Park, East Kilbride G75 0QF, UK. [email: Gordon.Cook@ glasgow.ac.uk]

Derek Hamilton is a Research Fellow at the University of Glasgow in the Radiocarbon Laboratory of the Scottish Universities Environmental Research Centre. His interests focus on the Iron Age of Britain and the near Continent, and the application of scientific methods for better understanding indigenous settlement and society around the time of Roman expansion through north-western Europe. A primary interest has been the development of robust and precise chronological frameworks, which can be integrated with other forms of qualitative and quantitative data to understand this period of contact and colonization in late prehistoric/Roman Britain.

Address: Scottish Universities Environmental Research Centre, Rankine Avenue, Scottish Enterprise Technology Park, East Kilbride G75 0QF, UK. [email: Derek.Hamilton.2@ glasgow.ac.uk]

\section{Enquête sur la formation des sites et constitution du contexte local par " wiggle- matching " : révision des datations radiocarbone des crannogs du Firth of Clyde en Ecosse}

Il existe au moins quatre plateformes de bois, connues sous le nom de crannogs, dans la zone de marnage du Firth of Clyde sur la côte sud-ouest de l'Ecosse. Leur interprétation dépend en partie de leur chronologie et, si elles sont contemporaines, elles pourraient résulter de la formation d'un réseau marin autochtone. De plus, leur situation qui coïncide avec le terminus du Mur d'Antonin, a mené à des 
conjectures sur le rôle qu'elles auraient pu jouer dans les interactions entre Romains et indigènes pendant l'occupation de l'Ecosse du sud au début du premier millénaire apr. J.-C. Ainsi une meilleure chronologie absolue est essentielle pour vérifier si les crannogs marins étaient contemporains et si on peut les relier à des événements historiques. Notre article présente les résultats d'un projet de mise en concordance des oscillations des courbes de calibration ("wiggle-natching") qui a pour but de résoudre les incertitudes chronologiques sur deux crannogs, ceux de Dumbuck et d'Erskine Bridge. Les résultats démontrent clairement que la construction de ces sites est antérieure à l'influence romaine an Ecosse. De plus, ces résultats indiquent que les deux sites avaient été construits à un intervalle de 300 ans, ce qui nous oblige à considérer la possibilité qu'ils avaient été établis dans des contextes historiques fort différents. D'autres observations techniques concernent certains détails de la courbe de calibration autour du changement d'ère (av./apr. J.-C.) et la possibilité qu'il y ait eu une contamination persistante des parties exposées et pourries du bois d'aulne gorgé d'eau. Translation by Madeleine Hummler

Mots-clés: "wiggle-matching " des courbes de calibration radiocarbone, chronologie bayésienne, Âge du Fer en Ecosse, crannogs, habitats en zone de marnage, Firth of Clyde

\section{Untersuchung der Genese der Fundstellen und Aufbau der lokalen Rahmenbedingungen durch "Wiggle-Matching" von Radiokarbon Datierungen: neue Bewertung der Chronologie der Crannógs im Firth of Clyde, Schottland}

Es gibt mindestens vier Holzplattformen (sogenannte maritime Crannógs) in der Gezeitenzone des Firth of Clyde an der südwestlichen Küste Schottlands. Die Deutung dieser Fundstätten hängt teils von ihrer Datierung ab; falls sie gleichzeitig errichtet worden waren, könnten sie auf einen maritimen Knotenpunkt hinweisen. Darüber hinaus hat das räumliche Zusammentreffen mit dem Endpunkt des Antoninuswalls zu Spekulationen über die Rolle der maritimen Crannógs in den Wechselbeziehungen zwischen Römer und Einheimischen während der römischen Besetzung von Südschottland im frühen ersten Jahrhundert n.Chr. geführt. Deswegen ist es notwendig, eine absolute Chronologie aufzustellen, sodass man beurteilen kann, ob die maritimen crannógs zeitgenössisch waren und ob sie mit bekannten historischen Ereignissen verknüpft waren. In diesem Artikel werden die Resultate eines "WiggleMatching" Projektes vorgeführt, dessen Ziel darin besteht, diese Unklarheiten zu lösen. Dies wurde für zwei der betreffenden Fundstätten unternommen: Dumbuck und Erskine Bridge. Die Ergebnisse zeigen eindeutig, dass diese Fundorte vor dem Zeitpunkt des direkten römischen Einflusses in Schottland errichtet wurden. Die Resultate zeigen auch, dass die beiden Fundplätze in einem Abstand von wenigstens 300 Jahren gebaut wurden, was uns dazu zwingt in Betracht zu ziehen, dass diese Fundstätten möglicherweise in ganz verschiedenen bistorischen Zusammenhängen funktionierten. Weitere Erkenntnisse umfassen technische Betrachtungen der Form der Radiokarbon Kalibrationskurve um die Zeitenwende v. Chr./n Chr. und mögliche Nachweise auf eine anhaltende Kontamination von verrotteten und freiliegenden Abschnitten von Erlenholz, das wassergesättigt ist. Translation by Madeleine Hummler

Stichworte: Radiokarbon „Wiggle-Matching“, Datierung, Bayessche Chronologie, Eisenzeit in Schottland, Crannógs, Siedlungen in der Gezeitenzone, Firth of Clyde 